\title{
ANALYSIS OF THE EFFECTIVENESS OF ONLINE LEARNING ON STUDENTS DURING THE PANDEMIC PERIOD COVID-19 AT UNIVERSITY MALIKUSSALEH
}

\author{
Agus Muliaman', Fajrul Wahdi Ginting $^{2}$ \\ 1,2 University Malikussaleh, Aceh Utara \\ Correspondence Address : Jl. Cot Tengku Nie, Reulet Kab. Aceh Utara \\ E-mail: ${ }^{1)}$ agusmuliaman@unimal.ac.id
}

\begin{abstract}
The pandemic from the corona virus outbreak has paralyzed learning activities. Face-to-face learning cannot be done so that online learning is applied. The purpose of this research is to see the effectiveness of the learning process that has been going on so far. The place of this research is the Chemistry Education Study Program, Malikussaleh University with approximately 86 respondents as a sample of students. This research is quantitative research with survey method. The results of this study indicate that online learning is quite effective with a score of 3.21 (quite satisfied) but it is still far from being said to be effective with problems on the internet and health that burden students and lecturers, so that in the future most students (53.96\%) are still more choose to take courses offline.
\end{abstract}

Keywords: Covid-19, Online Learning, quantitative research

\section{INTRODUCTION}

Education is a form of embodiment of human culture and a condition for the development of progress. Therefore, changes or developments in education are things that should happen in line with changes in the culture of life. Changes in the sense of improving education at all levels need to be continuously carried out in anticipation of future interests(Trianto, 2009).

In the development of the world of education, many challenges are faced from various aspects, one of which can come from the health aspect. In 2019 originating from Wuhan, China, a virus called corona or Covid-19 emerged which finally spread throughout the world uncontrollably which made it difficult for all countries, both developed and developing countries, including Indonesia, which in the end Covid 19 was designated as a pandemic outbreak by the World Health Organization. (WHO) on March 12, 2020 (Karisma et al., 2020). Covid-19 is a new type of disease that has never been previously identified in humans (Astini, 2020). This disease can cause death, so far there have been many cases of death caused by this virus.

The Covid-19 pandemic has had a major impact on various fields (Solviana, 2020). One of the areas impacted by Covid 19 in Indonesia is education (Sulata \& Hakim, 2020), as a result, most schools and campuses are closed and do not study. Of course this will cause a bad effect on the quality of education in Indonesia. To overcome this, all parties must immediately find a powerful solution.

The selection of the right learning model based on the situation is a step that must be taken immediately (Muliaman \& Mellyzar, 2020;Mellyzar \& Muliaman, 2020). One of the learning models that can be done by universities is to apply online learning, so that the learning process can continue and the spread of the covid virus can be prevented, so that this is a win-to-win solution in dealing with this problem (Purnawati \& Krisnadi, 2020).

Online or online learning (on the network) is carried out through various applications (Suhada et al., 2019). A wide selection of applications for online lectures including zoom, googleclassroom, email, etc. This change in lecture habits is not necessarily without problems (Dewantara \& Nurgiansah, 2021). The change in learning methods from classical and face-to-face methods to online methods has received various reactions from students (Kusnayat et al., 2020) 
Students' reactions to learning are certainly diverse, some respond positively and some are negative. In addition, online learning is a new thing for students, so many are not used to it.

Online learning has been carried out for about 4 semesters at the Malikussaleh University, for that it requires evaluation and also needs to see the responses of students so that it can be seen whether the online learning that has been implemented is effective or not. Based on this, the researchers made this study.

\section{IMPLEMENTATION METHOD}

This research is an Expost Facto Survey research with a quantitative approach. This research was conducted at the Chemistry Education Study Program, Malikussalah University, for the 2021/2022 academic year. The population in this study were all students of the Chemistry Education Study Program who were still actively studying. The population of this study amounted to 152 students. The sample selection used purposive sampling, so that a total of 86 samples were obtained. This study uses a survey technique, the instrument used is a Likert scale online learning effectiveness questionnaire with a range of 1 to 5, ranging from very dissatisfied to very satisfied. The data analysis technique used descriptive analysis techniques.

\section{RESULTS AND DISCUSSION}

\section{Effectiveness of Online Learning}

Online learning is carried out by the Chemistry Education Study Program, Malikussaleh University for 2 semesters/ 1 year. During these 2 semesters, students study online with a maximum total of 24 credits with an average of 11 courses that must be followed. Whereas for 1 semester there are 16 meetings for 1 course, so the total calculation is that each student takes a maximum of 384 lesson hours for 1 semester, so that there is a maximum of 768 hours of lessons attended by each student online in this 1 year. Of course, with this large number, online learning must be evaluated by looking at student satisfaction with online learning so that it can be seen the effectiveness of online learning implemented in the Chemistry Education Study Program, Malikussaleh University. The results of the questionnaire survey which were filled in by students are shown in Table 1.

Table 1. Results of the Online Learning Effectiveness Survey

\begin{tabular}{clcc}
\hline No & Indicator of Effectiveness of Online Learning & Score & Description \\
\hline 1 & Easy to use online media & 3.31 & Quite Satisfied \\
2 & Online media used maximally & 3.31 & Quite Satisfied \\
3 & Submission of material went smoothly & 3.21 & Quite Satisfied \\
4 & The material presented is easy to understand & 3.01 & Quite Satisfied \\
5 & Materials are easily accessible through online media & 3.42 & Quite Satisfied \\
6 & Learning feels comfortable & 3.00 & Quite Satisfied \\
& Average & $\mathbf{3 . 2 1}$ & Quite Satisfied \\
\hline
\end{tabular}

Based on the data in the table above, it can be seen that 5 indicators are categorized as quite satisfied, only the 6th indicator gets less satisfied results, this is caused by several factors which will be explained later. But overall the average of all indicators got 3.21 results (quite satisfied), so it was found that online learning for Chemistry Education Study Program students can be said to be quite effective, but it is still far from being effective let alone very effective.

So that there is a maximum of 768 hours of lessons attended by each student online in this 1 year. Of course, with this large number, online learning must be evaluated by looking at student satisfaction with online learning so that it can be seen the effectiveness of online learning implemented in the Chemistry Education Study Program, Malikussaleh University. The results of the questionnaire survey which were filled in by students are shown in Table 1. 


\section{Online Learning Media}

The determination of online learning media also affects the results of online learning. Choosing the right learning media and preferred by students will enable more effective online learning. The results of the online learning media survey that students prefer can be seen in table 2 .

Table 2. Results of the Online Learning Media Survey

\begin{tabular}{cccc}
\hline No & Media Pembelajaran Daring & Responden & Persentase (\%) \\
\hline 1 & Zoom & 72 & 83.72 \\
2 & Portal E-Learning & 12 & 13.95 \\
3 & Google Classroom & 1 & 1.16 \\
4 & Individual Assignment & 1 & 1.16 \\
\hline
\end{tabular}

Based on the data in the table above, it can be seen that learning media through zoom is the most preferred with an acquisition of $83.72 \%$, while the second rank is the E-Learning portal at $13.95 \%$ and the last is Google Classroom and individual assignments with a percentage of 1.16. From these results, we can see that students prefer zoom, zoom is an easy and practical application where users can communicate audiovisually and it has other features such as displaying presentations, recording lessons, etc., so that it can support online learning optimally.

\section{Online Learning Problem}

The results of online learning that have been carried out so far can be categorized as quite effective, but of course it is still far from being effective and even very effective, therefore an evaluation must be carried out so that online learning in the future can take place optimally and get better results. In this evaluation the researcher found several problems in the online learning process which can be seen in table 3 .

Table 3. Results of the Online Learning Problem Survey

\begin{tabular}{cccc}
\hline No & Masalah Pembelajaran Daring & Responden & Persentase (\%) \\
\hline 1 & Unstable network & 46 & 53.49 \\
2 & Insufficient quota & 20 & 23.26 \\
3 & Difficult to focus & 13 & 15.12 \\
4 & Many tasks & 7 & 8.14 \\
\hline
\end{tabular}

Based on the survey results in the table above, it is found that the main problem in online learning is the problem with the internet, both on an unstable network (53.49\%) as well as an insufficient quota (23.26). This is because the use of zoom via laptops and computers, the use of zoom does have advantages but also has disadvantages, among others, requiring a very stable and fast network $(4 \mathrm{G})$ where only certain areas have this such as big cities or district capitals, while very few rural areas already have a stable $4 \mathrm{G}$ network. Zoom is an audiovisual communication application, therefore of course it requires quite a lot of quota, for 1 hour of zoom usage you can spend a minimum of 200-300 MB, also the quota price from a provider that has a fast, strong and stable network is not cheap, imagine me if in 1 day there are about 4-6 hours of learning that must be followed, of course this will burden students and lecturers. Another problem is that using a laptop/computer for hours every day can also cause health problems such as nearsightedness and difficulty focusing. Too many assignments can also be difficult for students.

\section{Learning Model}

It has been discussed above that online learning is quite effective and has its own advantages and disadvantages. Apart from of course for the future, of course we have to choose a learning model that is more suitable for use than the students' own choices. The survey results can be seen in table 4. 
Table 4. Results of the Preferred Learning Model Survey

\begin{tabular}{cccc}
\hline No & Model Pembelajaran & Responden & Persentase (\%) \\
\hline 1 & Offline Learning & 49 & 56.98 \\
2 & Online Learning & 25 & 29.07 \\
3 & Blended & 12 & 13.95 \\
\hline
\end{tabular}

Based on the table, it can be seen that the learning model preferred by students with the highest results is shown offline learning at $56.98 \%$, followed by online learning $29.07 \%$ and blended (a mixture of offline and online) at 13.95\%. The results show that apart from effective learning outcomes, the desire of students to attend lectures on campus face-to-face is still high, this is because direct learning makes it easier for students and lecturers to interact directly and communicate directly, as well as minimizing miscommunication and misinterpretation in the process of delivering material by lecturer. In addition, students also miss the campus atmosphere where students can do other activities besides studying, such as honing skills in certain SMEs or visiting campus facilities such as the library to find the references they need.

\section{CONCLUSION}

Based on the findings and discussion, it can be concluded that online learning for chemistry students at Malikussaleh University is quite effective. although effective is still very far from being effective, it also has drawbacks, namely problems with the internet and health that burden students and lecturers, so that in the future most students still prefer to take lectures offline.

\section{REFERENCES}

Astini, N. K. S. (2020). Pemanfaatan Teknologi Informasi Dalam Pembelajaran Tingkat Sekolah Dasar Pada Masa Pandemi Covid-19. Jurnal Lampuhyang, 11(2), 13-25.

Dewantara, J. A., \& Nurgiansah, T. H. (2021). Efektivitas Pembelajaran Daring di Masa Pandemi COVID 19 Bagi Mahasiswa Universitas PGRI Yogyakarta. Jurnal Basicedu, 5(1), 367-375.

Karisma, N. N., Roesminingsih, M. V., \& Suhanadji, S. (2020). Gambaran Kebutuhan Pembelajaran Daring PKBM Budi Utama Surabaya Pada Masa Pandemi Covid-19. Jurnal Pendidikan Non Formal, 15(1), $38-44$.

Kusnayat, A., Muiz, M. H., Sumarni, N., Mansyur, A. S., \& Zaqiah, Q. Y. (2020). Pengaruh Teknologi Pembelajaran Kuliah Online Di Era Covid-19 Dan Dampaknya Terhadap Mental Mahasiswa. EduTeach: Jurnal Edukasi Dan Teknologi Pembelajaran, 1(2), 153-165.

Mellyzar, M., \& Muliaman, A. (2020). Analisis Kesalahan Mahasiswa Dalam Menyelesaikan Soal Ikatan Kimia. Lantanida Journal, 8(1), 40-52.

Muliaman, A., \& Mellyzar, M. (2020). Peningkatan Hasil Belajar Menggunakan Model Project Based Learning Pada Materi Laju Reaksi. Chemistry in Education, 9(2), 91-95.

Purnawati, E., \& Krisnadi, I. (2020). Implementasi Sistem Perkuliahan Daring Berbasis ICT Dalam Masa Pandemi Wabah Covid -19. Pascasarjana Program Magister Teknik Elektro Universitas Mercu Buana, 1(1), 1-12.

Solviana, M. D. (2020). Pemanfaatan Teknologi Pendidikan di Masa Pandemi Covid-19: Penggunaan Fitur Gamifikasi Daring di Universitas Muhammadiyah Pringsewu Lampung. Al-Jahiz: Journal of Biology Education Research, 1(1), 1-14.

Suhada, I., Kurniati, T., Pramadi, A., \& Listiawati, M. (2019). Pembelajaran Daring Berbasis Google Classroom Mahasiswa Pendidikan Biologi Pada Masa Wabah Covid-19. Digital Library UIN Sunan Gunung Jati, 1-9. http://digilib.uinsgd.ac.id/30584/

Sulata, M. A. H., \& Hakim, A. A. (2020). Gambaran Perkuliahan Daring Mahasiswa Ilmu Keolahragaan UNESA Di Masa Pandemi Covid-19. Jurnal Kesehatan Olahraga, 8(3), 147-156.

Trianto. (2009). Mendesain Model Pembelajaran Inovatif-Progresif. In Kencana. 